\title{
Human Umbilical Cord Blood Stem Cells Differentiate into Keratinocytes under In Vitro Conditions and Culturing Differentiated Cells on Bacterial Cellulose Film
}

\author{
Research Article
}

Yavari $\mathrm{K}^{1 *}$, Abolhassani $\mathrm{S}^{2}$, Mohammadnejad J²

${ }^{1}$ Nuclear Science and Technology Research Institute, (NSTRI), Tehran, Iran.

${ }^{2}$ Faculty of New Sciences and Technologies, Department of Life Science Engineering, University of Tehran, Tehran, Iran.

\section{Abstract}

\begin{abstract}
Mesenchymal stem cells (MSC) are capable of self renewing and differentiating into other cell types. Human umbilical cord blood (HUCB) has been investigated as an alternative source to bone marrow. The aim of our examinations was to investigate MSC of HUCB could differentiate into keratinocytes under in vitro conditions. In this study, we examined the differentiation with chemical compounds, then to identify the stem cells are differentiated or not, PCR by using the expression of gene cytokeratin 18 was performed and to examine the proliferation characteristic of differentiated keratinocyte from HUCBMSCs, cultured them on cellulose film. Analysis of PCR confirmed the expression of cytokeratin 18 in keratinocytes; results of our study show that cellulose film isn't a compatible substrate for differentiated keratinocytes. And growth factor, BMP4, with hydrocortisone and ascorbic acid with specific amounts is an appropriate induction factor for inducing of differentiation into keratinocytes.
\end{abstract}

Keywords: Keratinocyte; Cytokeratin 18; Cellulose Film; Mesenchymal Stem Cell.

\section{Introduction}

Our body surface is covered by epithelial tissue which provides a protective barrier. Damaging to this tissue must be healed by cell operation. One of the possible origins of the cells involved in tissue repair after damaging is stem-like progenitor cells, which are the most important but scarce components of the proliferative compartment of an epithelial tissue [1]. Primary efforts in order to accelerate wound healing and promoting the quality of healing in chronic wounds or burn injuries, included the use of biological or artificial coverings. Although these materials were effective but did not cause any permanent health effects because eventually for access the full recovery, we need transplantation and this due to damaging to the part of the donor's body is undesirable [2]. Developing tissue engineered constructions made major changes in treatment of an ulcer [3-5]. These constructions can be classified into two main groups: with and without cells [2]. MSCs can be useful in many pathological conditions, though the mechanism of their action is still unknown [6]. Some problems by these con- structions are slow and insufficient vascularization of large ones [7]. Skin tissue engineering has been in the forefront of tissue engineering for many years and now some of its products are available. Tissue-engineered skin substitutes are divided into two general groups, cell based products, which can stimulate wound healing and cell-free products, which are cover for injury [8]. In most studies which have been done for differentiation into skin cells, the co culture method has been used to induce differentiation [9-15]. In this study, we examined the differentiation with chemical compounds $[16,17]$.

Umbilical cord blood is a source of mesenchymal and hematopoietic stem cells [18-20]. Human MSCs are self-renewal and can be differentiated into mesenchymal and non-mesenchymal cells [21, 22]. Compared to isolation of stem cells from bone marrow, isolation from this source is more simple and easier, safer and painless $[10,23]$. And some shows that isolation of stem cells from Wharton's Jelly is even easier and faster [24, 25].

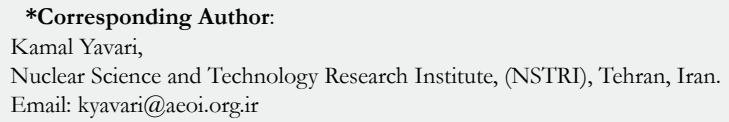

Citation: Yavari K, Abolhassani S, Mohammadnejad J (2016) Human Umbilical Cord Blood Stem Cells Differentiate into Keratinocytes under In Vitro Conditions and Culturing Differentiated Cells on Bacterial Cellulose Film. Int J Stem Cell Res Transplant. 04(7), 216-219. doi: http://dx.doi.org/10.19070/2328-3548-1600033

Copyright: Yavari $\mathbf{K}^{\circ}$ 2016. This is an open-access article distributed under the terms of the Creative Commons Attribution License, which permits unrestricted use, distribution and reproduction in any medium, provided the original author and source are credited. 


\section{Materials and Methods}

\section{Induction of MSC into keratinocyte differentiation}

MSCs were cultured into 6-well plate. We investigated 4 different mediums and 2 periods of times which are shown in Table 1.

The plates were checked daily under invert microscope and the changes in morphology of cells were photographed which some of them are shown in results.

\section{Polymerase chain reaction (PCR)}

After culturing in each one of mediums stated (Table 1), to identify the stem cells are differentiated or not, polymerase chain reaction was performed on total RNA extracted from cultured cells. We investigate the expression of gene cytokeratin 18. Total RNA from the cultured cells was extracted using QIAGEN RNeasy plus mini kit. This kit can be used in a wide range of cells and removes the contamination of DNA during extraction [26]. RNA was measured by using optical density method at $260 \mathrm{~nm}$ wavelength. Using Beer Lambert law, the amount of light absorbed can be attributed to the concentration of absorbing molecules. At the wavelength of $260 \mathrm{~nm}$, the extinction coefficient for one strand RNA is $0.025(\mu \mathrm{g} / \mathrm{ml})^{-1} \mathrm{~cm}^{-1}$. Thus, the optical density of 1 , equals to $40 \mu \mathrm{g} / \mathrm{ml}$ for one strand RNA [27]. Then cDNA was synthesized by using Revertaid first strand cDNA synthesis kit [28]. Synthesized cDNAs should be proliferated by specific primers. PCR or polymerase chain reaction is a simple, meanwhile a sensitive method for replication of a particular piece of DNA in the laboratory. Primer cytokeratin 18 was as follows: (sense) 5'-CAAGGAGGAGCTGCTGCTCTTCATG-3', (antisense), 5'-CAGCAGATTGAGGAGAGCACCA-3'. The temperatures, times and number of cycles are shown in Table 2.

The PCR was done on a C 1000 thermal cycler (BIO-RAD). The reactions were done in a total volume of $25 \mu$ containing $10 \mu \mathrm{M}$ of each primer, DNA template $0.2 \mu \mathrm{g}$ and Master Mix $2 \mathrm{x} 12.5 \mu \mathrm{l}$. And finally to examine the proliferation characteristic of differentiated keratinocyte from HUCBMSCs, cultured them on cellulose film. For this purpose, first the cellulose film was purified and then was dried. Cellulose obtained from fermentor containing impurities such as bacterial cells and compounds of culture medium. For making it purified, first the cellulose in the form of a square were cut then in $\mathrm{NaOH}$ solution of $0.1 \mathrm{M}, 3$ times and each time boiled for $30 \mathrm{~min}$, then placed in incubator at $37^{\circ} \mathrm{C}$ as long were dried. After cellulose film being dried in the incubator, the cell suspension containing approximately $5 \times 10^{4}$ differentiated cells in $1 \mathrm{ml}$ of culture medium was poured onto cellulose film in wells of a 6 well plate. After $48 \mathrm{~h}$ exposure to the incubator, preparation for SEM analysis was performed.

To study cell adhesion to cellulose fibers, we used scanning electron microscopy. To prepare samples, first they were washed in PBS, and then fixed in glutaraldehyde $2.5 \%$ for $90 \mathrm{~min}$; dewatering by using ethanol solutions with concentration gradient of $30 \%, 50 \%, 70 \%, 90 \%$ and $95 \%$, each one for $15 \mathrm{~min}$ was done. In the next step for making conductive, the surface of samples was covered with a thin layer of gold by using sputtering coater method.

\section{Results}

\section{The morphology of differentiated mesenchymal stem cells}

To investigate the differentiation to keratinocytes, cells were observed daily under the inverted microscope. Figure 1 shows the cells 9 days after induction of differentiation.

The concentration of purified RNA was $2400 \mu \mathrm{g} / \mathrm{ml}$ by using Bio Photo Meter and explanations provided in the Materials and methods section. By using PCR analyzing, the gene expression of cytokeratin 18, skin cell-specific gene was examined as shown at Figure 2.

To study the proliferation characteristic of differentiated keratinocyte from HUCBMSCs on cellulose film, we used SEM. Figure 3 shows the cells after 48 hours of culturing them on a cellulose film.

Table 1. Concentration of compounds in culture medium of mesenchymal stem cells for differentiation into keratinocyte and the number of days in this medium.

\begin{tabular}{|c|c|c|c|}
\hline Hydrocortisone & Ascorbic acid & BMP-4 & Time \\
\hline $0.5 \mu \mathrm{g} / \mathrm{ml}$ & $5 \mu \mathrm{g} / \mathrm{ml}$ & - & 10 days \\
\hline $0.5 \mu \mathrm{g} / \mathrm{ml}$ & $5 \mu \mathrm{g} / \mathrm{ml}$ & - & 20 days \\
\hline $0.5 \mu \mathrm{g} / \mathrm{ml}$ & $5 \mu \mathrm{g} / \mathrm{ml}$ & $20 \mathrm{ng} / \mathrm{ml}$ & 10 days \\
\hline $0.5 \mu \mathrm{g} / \mathrm{ml}$ & $5 \mu \mathrm{g} / \mathrm{ml}$ & $20 \mathrm{ng} / \mathrm{ml}$ & 20 days \\
\hline
\end{tabular}

Table 2. Number of cycles, time and temperature of PCR for identification of gene cytokeratin 18 in differentiated stem cells into keratinocytes.

\begin{tabular}{|c|c|c|}
\hline Number of cycles & Time & Temperature \\
\hline 1 & $3 \mathrm{~min}$ and $30 \mathrm{sec}$ & $95^{\circ} \mathrm{C}$ \\
\hline 40 & $10 \mathrm{sec}$ & $95^{\circ} \mathrm{C}$ \\
\hline 30 & $30 \mathrm{sec}$ & $58^{\circ} \mathrm{C}$ \\
\hline 30 & $30 \mathrm{sec}$ & $70^{\circ} \mathrm{C}$ \\
\hline 1 & $5 \mathrm{~min}$ & $73^{\circ} \mathrm{C}$ \\
\hline
\end{tabular}


Figure 1. Shows the cells 9 days after induction of differentiation.

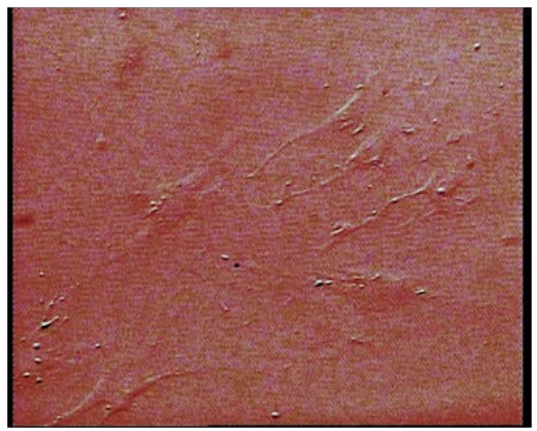

Figure 2. Using PCR analyzing, the gene expression of cytokeratin 18, skin cell-specific gene was examined.

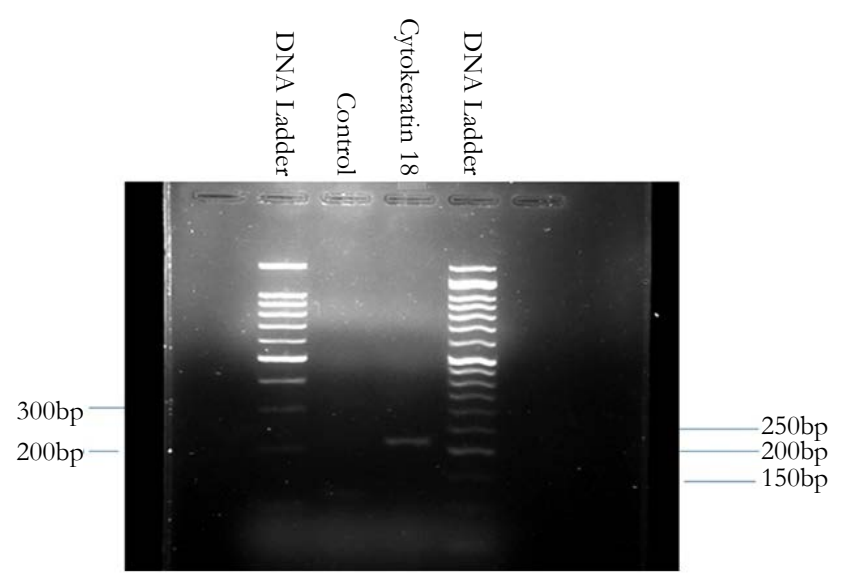

Figure 3. The keratinocytes after 48 hours of culturing them on a cellulose film (magnification $6000 x$ ).

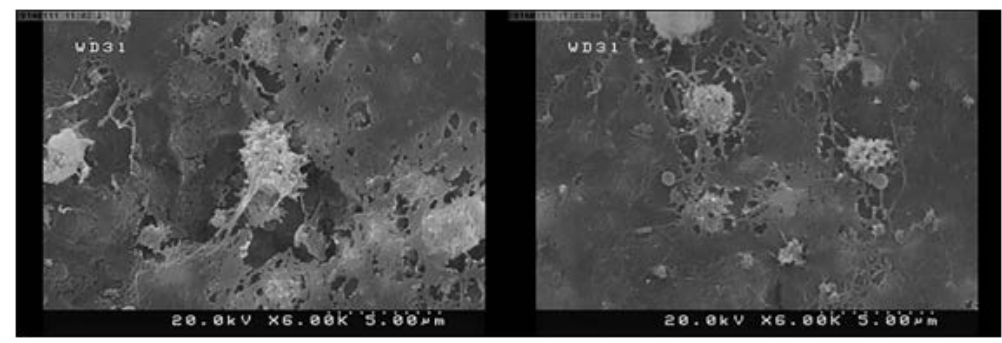

\section{Discussion}

The changes in the appearance of cells can be observed in Figure 1. One of these changes is that spindle like shape cells, become wider. As shown in Figure 2, differentiated cells expressed the gene cytokeratin 18 well. However, the expression of this gene has not been observed in control cells which are undifferentiated MSCs. Previously in other studies the differentiation of stem cells to cutaneous cells was confirmed [1, 9, 29-34].

As figure shows, in order to study the expression of gene cytokeratin 18; two types of ladder one with a gap distance of 50 bp and one with $100 \mathrm{bp}$ is used. After the primer was purchased from Sina Clon Company, the gene sequence was obtained from Pubmed-NCBI site. Gene length was equal to 221 bp which, as both ladders show, the band is located in the appropriate distance.

The results of SEM are comparable to results that have been reported by HL Almedia et al., about morphology of these cells which expressed they are round or polygonal [35]. The cells didn't show a good adhesion and extension as you can see in Figure 3. If the environment is favorable for the cells, they will spread on the surface but if the environment isn't favorable, the cells will place with distance from each other and are wrinkled and don't make strong connections with their substrate. But about these cells, differentiated keratinocyte from stem cells, we can't definitely say that this substrate isn't appropriate, because these cells are extremely sensitive and the slight change in the culture medium of these cells can be consider as a risk for them. In a study by Neeracha Sanchavanakit et al., bacterial cellulose film has been introduced as an appropriate substrate for keratinocytes [36].

\section{Conclusion}

Growth factor, BMP4, is an appropriate induction factor for inducing of differentiation into keratinocytes. We can't definitely say that cellulose film is not a suitable substrate for keratinocytes but results of our study show that it's not a compatible substrate for differentiated keratinocytes.

\section{References}

[1]. Păunescu V, Deak E, Herman D, Siska IR, Bunu C, et al., (2007) In vitro differentiation of human mesenchymal stem cells to epithelial lineage. Jour- 
nal of cellular and molecular medicine 11(3): 502-508.

[2]. Clark RA, Ghosh K, Tonnesen MG (2007) Tissue engineering for cutaneous wounds. Journal of Investigative Dermatology 127(5): 1018-1029.

[3]. Gnecchi M, Danieli P, Malpasso G, Ciuffreda MC (2016) Paracrine Mechanisms of Mesenchymal Stem Cells in Tissue Repair. Methods Mol Biol 1416: $123-146$

[4]. Frykberg R, Cazzell S, Arroyo-Rivera J, Tallis A, Reyzelman A, S et al., (2016) Evaluation of tissue engineering products for the management of neuropathic diabetic foot ulcers: an interim analysis. Journal of Wound Care 25(Sup7): S18-S25.

[5]. Maione AG, Smith A, Kashpur O, Yanez V, Knight E, et al., (2016) Altered ECM deposition by diabetic foot ulcer-derived fibroblasts implicates fibronectin in chronic wound repair. Wound repair and regeneration 24(4): 630-43.

[6]. Dolcetti L, Dazzi F (2015) Therapeutic Immunomodulation with Mesenchymal Stromal Cells: The Need for In Vivo Clues. Int J Transla Sci 1(10.13052): 23-40.

[7]. Zhang W, Wray LS, Rnjak-Kovacina J, Xu L, Zou D, et al., (2015) Vascularization of hollow channel-modified porous silk scaffolds with endothelial cells for tissue regeneration. Biomaterials 56: 68-77.

[8]. Lanza R, Langer R, Vacanti JP (2011) Principles of tissue engineering. ( ${ }^{\text {rd }}$ edn), Academic press, London.

[9]. Mollah ZU, Aiba S, Manome H, Yoshino Y, Tagami H ( 2002) Cord Blood CD34\&plus; Cells Differentiate into Dermal Dendritic Cells in Co-Culture with Cutaneous Fibroblasts or Stromal Cells. Journal of Investigative Dermatology 118(3): 450-460

[10]. Kamolz L-P, Kolbus A, Wick N, Mazal P, Eisenbock B, et al., (2006) Cultured human epithelium: human umbilical cord blood stem cells differentiate into keratinocytes under in vitro conditions. Burns 32(1): 16-19.

[11]. Meana A, Iglesias J, Del Rio M, Larcher F, Madrigal B, et al., (1998) Large surface of cultured human epithelium obtained on a dermal matrix based on live fibroblast-containing fibrin gels. Burns 24(7): 621-630.

[12]. Rubin JS, Osada H, Finch PW, Taylor WG, Rudikoff S, et al., (1989) Purification and characterization of a newly identified growth factor specific for epithelial cells. Proceedings of the National Academy of Sciences 86(3): 802-806.

[13]. Finch PW, Rubin JS, Miki T, Ron D, Aaronson SA (1989) Human KGF is FGF-related with properties of a paracrine effector of epithelial cell growth. Science 245(4919): 752-755.

[14]. Barreca A, de Luca M, Monte PD, Bondanza S, Damonte G, et al., (1992) In vitro paracrine regulation of human keratinocyte growth by fibroblastderived insulin-like growth factors. Journal of cellular physiology 151(2): 262-268.

[15]. Haubner F, Muschter D, Pohl F, Schreml S, Prantl L, et al., (2015) A coculture model of fibroblasts and adipose tissue-derived stem cells reveals new insights into impaired wound healing after radiotherapy. International journal of molecular sciences 16(11): 25947-25958.

[16]. Sasaki M, Abe R, Fujita Y, Ando S, Inokuma D, et al., (2008) Mesenchymal stem cells are recruited into wounded skin and contribute to wound repair by transdifferentiation into multiple skin cell type. The Journal of immunology 180(4): 2581-2587.

[17]. Toai TC, Thao HD, Gargiulo C, Thao NP, Thuy TTT, et al., (2011) In vitro culture of Keratinocytes from human umbilical cord blood mesenchymal stem cells: the Saigonese culture. Cell and tissue banking 12(2): 125-133.

[18]. Chiu B, ZM Wan J, Abley D, Akabutu J (2005) Induction of vascular endothelial phenotype and cellular proliferation from human cord blood stem cells cultured in simulated microgravity. Acta astronautica 56(9): 918-922.

[19]. Ventura Ferreira MS, Jahnen-Dechent W, Labude N, Bovi M, Hieronymus T, et al., (2012) Cord blood-hematopoietic stem cell expansion in 3D fibrin scaffolds with stromal support. Biomaterials 33(29): 6987-97.

[20]. Kelly S, Sola C, De Lima M, Shpall E (2009) Ex vivo expansion of cord blood. Bone marrow transplantation 44(10): 673-681.

[21]. Chang KC, Hung SC (2016) Hypoxia-preconditioned allogeneic mesenchymal stem cells can be used for myocardial repair in non-human primates. journal of thoracic disease 8(7): E593-E595.

[22]. Cao Y (2015) S-nitrosoglutathione reductase-dependent PPARgamma denitrosylation participates in MSC-derived adipogenesis and osteogenesis. J Clin Invest 125(4): 1679-91.

[23]. Wagner W, Wein F, Seckinger A, Frankhauser M, Wirkner U, et al., (2005) Comparative characteristics of mesenchymal stem cells from human bone marrow, adipose tissue, and umbilical cord blood. Experimental hematology 33(11): 1402-1416

[24]. van der Garde M, van Pel M, Millán Rivero JE, de Graaf-Dijkstra A, Slot MC, et al., (2015) Direct Comparison of Wharton's Jelly and Bone Marrow-Derived Mesenchymal Stromal Cells to Enhance Engraftment of Cord Blood CD34+ Transplants. Stem cells and development 24(22): 2649-2659.

[25]. Secunda R, Vennila R, Mohanashankar AM, Rajasundari M, Jeswanth S, et al., (2015) Isolation, expansion and characterisation of mesenchymal stem cells from human bone marrow, adipose tissue, umbilical cord blood and matrix: a comparative study. Cytotechnology 67(5): 793-807.

[26]. Kanof M, Smith P, Zola H (1991) Preparation of human mononuclear cell populations and subpopulations. Current protocols in immunology 2: 7.1.

[27]. Sambrook J, Russell D (2001) Molecular Cloning: A Laboratory Manual. (3rd edn) Cold Spring Harbor laboratory. Cold Spring Harbor, NY.

[28]. Zilinskiene J (2006) RevertAid First Strand cDNA Synthesis Kit. Thermo Scientific 1-2.

[29]. Ma K, Laco F, Ramakrishna S, Liao S, Chan CK (2009) Differentiation of bone marrow-derived mesenchymal stem cells into multi-layered epidermislike cells in 3D organotypic coculture. Biomaterials 30(19): 3251-3258.

[30]. Jin G, Prabhakaran MP, Ramakrishna S (2011) Stem cell differentiation to epidermal lineages on electrospun nanofibrous substrates for skin tissue engineering. Acta Biomaterialia 7(8): 3113-3122.

[31]. Li H, Xu Y, Fu Q, Li C (2012) Effects of multiple agents on epithelial differentiation of rabbit adipose-derived stem cells in $3 \mathrm{D}$ culture. Tissue Engineering Part A 18(17-18): 1760-1770.

32]. Han Y, Chai J, Sun T, Li D, Tao R (2011) Differentiation of human umbilical cord mesenchymal stem cells into dermal fibroblasts in vitro. Biochemi$\mathrm{cal}$ and biophysical research communications 413(4): 561-565.

[33]. Rodriguez-Menocal L, Shareef S, Salgado M, Shabbir A, Van Badiavas E (2015) Role of whole bone marrow, whole bone marrow cultured cells, and mesenchymal stem cells in chronic wound healing. Stem cell research \& therapy 6(1): 1

[34]. Isakson M, de Blacam C, Whelan D, Mc Ardle A, Clover A (2015) Mesenchymal stem cells and cutaneous wound healing: current evidence and future potential. Stem cells international 2015: 1-12.

[35]. Almeida Jr HLd, Leitão AH, Rossi G, Rocha NM, Silva RM (2013) Scanning electron microscopy of acantholysis in pemphigus foliaceus. Anais Brasileiros de Dermatologia 88(3): 456-458.

[36]. Sanchavanakit N, Sangrungraungroj W, Kaomongkolgit R, Banaprasert T, Pavasant P, et al., (2006) Growth of human keratinocytes and fibroblasts on bacterial cellulose film. Biotechnology progress 22(4): 1194-1199. 